Sykepleierutdanning

\title{
Samarbeid i praksis
}

Innføring av faste samarbeidsmøter og avklaring av roller styrket samarbeidet mellom høyskole og praksisfelt

\section{Forfattere}

Kari Dahl

Førstelektor

Høgskolen i Oslo og Akershus

Ann Kristin Bjørnnes

høgskolelektor

Fakultet for helsefag, Høgskolen i Oslo og Akershus

Mari Skanche Bjerknes

Førstelektor

Ellen Reine

Institusjonssjef

Mette B. Brustad

Fagutviklingssykepleier

Sykepleien 2012 100(9)(50-52)

DOI: https://doi.org/10.4220/sykepleiens.2012.0089

Denne artikkelen bygger på et samarbeidsprosjekt

mellom Oslo kommune, Tåsenhjemmet og sykepleierutdanningen ved Høgskolen i Oslo og Akershus. Prosjektet ble tildelt samarbeidsmidler for perioden 2010-2011, og vi har brukt modifisert aksjonsforskningsdesign som metode (1). Målet var å fremme kunnskapsbasert sykepleie på sykehjemmet, samt å utvikle en allerede god praksisplass. 


\section{Tåsen sykehjem}

Sykehjemmet har 140 pasienter og 130 stillinger hvorav 46 er sykepleiere. Hjemmet er inndelt i seks avdelinger med tre langtids somatiske avdelinger, en skjermet enhet, en korttidsavdeling og en trygghetsavdeling. Sykehjemmet tar hvert år imot 24 førsteårsstudenter i tre praksisperioder over åtte uker. 60 førsteårsstudenter fordelt over fire praksisperioder deltok i prosjektet. Studentene ble fordelt gjennom høyskolens ordinære fordeling av praksis. Fire lærere var involvert. Prosjektleder var med i alle periodene. I artikkelen omtaler vi ulike intervensjoner for å styrke praksisopplæringen og hva vi erfarte må til for å fremme et vellykket samarbeid mellom høyskole og sykehjem.

\section{Historikk}

Historisk sett har praksisopplæring av studenter endret seg i takt med revidering av utdanningens rammebetingelser. Randi Nord skrev allerede i 1981 (2 s. 186) «Det er styrke i enhet, og sykepleiens største problem er kanskje mangel på enhet. Det eksisterer en barriere mellom sykepleierutdanning og sykepleieservice». Flere forfattere har siden fokusert på utviklingen av praksisopplæringen i Norge, spesielt endringer som har vært knyttet til at utdanningen er blitt løsrevet fra yrkesfeltet, administrativ og pedagogisk selvstendiggjøring, samt studentens statusendring fra elever til høyskolestudenter (3-6). Ulike studier har fokusert på sykepleierstudenters læring i praksis og forholdet mellom teori og praksis i utdanningen (3,7-9). Under praksisperioden utvikler studentene sin profesjonelle handlingskompetanse innenfor andre handlingskontekster enn de høyskolen representerer til daglig (10). Dette problematiseres som et gap mellom teori og praksis i utdanningen, til tross for at man har prøvd ut nye modeller for praksisundervisning (11-13). 


\section{Rammeplanen}

Rammeplanen for sykepleierutdanningen (2008) gir retningslinjer for ansvarsfordelingen mellom høyskolen og praksisfeltet. I tillegg er det vanlig at den enkelte høyskolen inngår avtaler med praksisfeltet, både om antall studenter, praksisperiodens varighet, veiledningstilbud, økonomisk kompensasjon og gjensidige forpliktelser. Ifølge rammeplanen skal man utarbeide en gjensidig forpliktende ansvarsfordeling. Videre skal avtalen sikre at veiledningsarbeidet er tydelig lederforankret (s. 11) og at veileder er kompetent til å veilede studenter. Slik kompetanse innebærer å vurdere faglighet, herunder etiske aspekter ved yrkesutøvelsen, samt skikkethet. I tillegg skal veileder fortrinnsvis være sykepleier.

Utdanningsinstitusjonene har ansvar for systematisk å bygge veiledningskompetanse.

\section{Praksismodeller}


Tradisjonelt har mester/svenn-modellen hvor en sykepleier har ansvar for en student $(3,7,14)$, vært mest anvendt som modell for praksisundervisningen. Denne modellen er basert på erfaringslæring og situert læring, hvor studentene lærer og reflekterer sammen med en erfaren sykepleier. En annen modell er tospannmodellen, hvor to og to studenter går sammen til samme brukere. De to studentene lærer av hverandre og veiledningen gis av en eller flere sykepleiere (15). Tospannmodellen er knyttet opp mot et sosiokulturelt læringssyn (9), mens mester/svennmodellens læringssyn er basert på at studenten lærer av eksperten(7).

I praksisperiodene har studenten rollen som legitim, perifer deltaker i ulike praksisfellesskap (10). Det betyr at studenten tilegner seg den typen kunnskap som handler om hvordan den aktuelle yrkesutøvelsens problemer og fenomener manifesterer seg i praksis. Gjennom å handle aktivt innenfor ulike kontekster i samspill med andre deltakere erfarer studenten mening, fellesskap og tilegner seg praktiske ferdigheter. Slik utvikler studenten sin yrkesidentitet gjennom gradvis å kvalifiseres til sykepleier (16).

\section{Pilotstudie}

Den første praksisperioden i prosjektet ble utformet som en pilotstudie og fant sted på en korttids- og rehabiliteringsavdeling, hvor åtte førsteårsstudenter hadde sin praksisperiode. Hele pleiepersonalet hadde ansvar for veiledning av studentene, samtidig som en studentkoordinator i 20 prosent stilling fungerte som bindeledd mellom de ansatte i avdelingen og høyskolen. Studenter, lærer og ansatte skulle sammen utvikle, implementere og evaluere kunnskapsbasert sykepleie. Vi etablerte to fokusgrupper med ansatte og studenter som skulle ledes av lærere fra høyskolen. Det ble avtalt faste møter en gang i uken strukturert etter trinnene i kunnskapsbasert praksis (17).

\section{Ikke vellykket}


Seks måneder etter prosjektstart viste imidlertid resultatene at organiseringen ikke var vellykket på grunn av uklare forventninger. På bakgrunn av dette ble det fra høsten 2010 fokusert mer på samarbeid. Tospannmodellen ble gjeninnført og praksiskoordinatorfunksjonen avviklet. Man innførte forberedende møter før studenten kom ut i praksis og velkomstmøter da studentene startet praksisperioden. Intensjonen var å bli kjent både med hverandre og praksisstedet, gi informasjon, stille spørsmål og diskutere, samt å avklare gjensidige forventninger. I alle praksisperiodene ble det i tillegg avviklet tre felles fagmøter. Hensikten var at ansatte, studenter og lærere skulle etablere et felles faglig fokus. Tema var sykepleiedokumentasjon, etikk, kunnskapsbasert sykepleie og refleksjon over praksis. I tillegg ble det tilbudt undervisning i kunnskapsbasert sykepleie i alle prosjektets faser. Vi gjennomførte også et to dagers kurs i kunnskapsbasert sykepleie overfor åtte sykepleiere inne på høyskolen $(17,18)$. I løpet av to praksisperioder hadde studentene en studieoppgave knyttet til fagutvikling og kunnskapsbasert sykepleie.

\section{Evaluering}

Prosjektet ble kontinuerlig evaluert og resultatene er basert på skriftlige og muntlige evalueringer fra studenter og kontaktsykepleiere etter hver praksisperiode og prosjektleders dagboknotater. Halvparten av de 60 studentene og 46 sykepleiere som var involvert i prosjektets siste del, besvarte spørreskjemaene.

Ifølge Bjørk og Bjerknes (5) bidrar klare avtaler mellom høyskole og praksisfelt til å kvalitetssikre praksisstudiene, og et godt samarbeid mellom ansatte i høyskole og praksis er svært viktig for studentenes læring $(19,20)$. Hovedfunnene i prosjektet viser at samarbeid er særlig viktig innen to hovedområder: 1) faste samarbeidsmøter og 2) synliggjøring av rollene i høyskolen og praksisfeltet.

\section{Møter}


Det forberedende møtet viste at forutsigbarhet skaper trygghet både for ansatte ved sykehjemmet og høyskolen. Alle avdelinger var representert og møtet ble evaluert positivt av alle. Sykepleierne oppfattet velkomstmøtene som viktig, nødvendig og noe som må fortsette. Enkelte ønsket at det skulle være mer informativt og ha en klarere hensikt.

Studenter og lærere opplevde møtene som informative og positive, men noe travelt når mange studenter skulle formidle sine forventninger. Dette førte til at sykepleier og lærer ikke alltid fikk mulighet til å konkretisere sine forventninger.

\section{Felles fagmøte}

Studentene evaluerte spesielt etikkdiskusjonen i fagmøtene positivt. Her hadde de med seg etiske dilemmaer som ble diskutert i grupper. De ansatte som møtte opp var aktive og opplevde møtene som positive. Refleksjon over praksis med rollespill som en av metodene ble også evaluert positivt av de ansatte og de fleste av studentene. De andre temaene på fellesmøtene ble både positivt og negativet evaluert av studentene.

På fagmøtene møtte fra tre-fire til ingen sykepleiere opp. Vi stilte derfor følgende spørsmål på siste evalueringsskjema: Hva skal til for at du er med på møtene? Sykepleierne svarte: Bedre planlegging og prioritering. På spørsmål om hvilke temaer de ønsker å diskutere, var svaret: Samarbeid, svake studenter og regler for studentene. Høyskolen på sin side ønsket å ta opp sykepleiefaglige temaer som dokumentasjon, kunnskapsbasert sykepleie og etikk. Det kan tenkes at misforståelsen handler om at vi har uklare forventninger til hverandre, at formidlingen fra skolens side har vært uklar eller at interessen for det man skulle ta opp ikke ble opplevd som relevant.

\section{Mer informasjon}


Bedre tilrettelegging, mer informasjon om prosjektets hensikt og mål, samt undervisning om kunnskapsbasert praksis for kontaktsykepleierne, ville sannsynligvis ha gjort kontaktsykepleierne bedre forberedt og motivert dem til å delta mer aktivt på fagmøtene. Sykepleiere som skal delta i slike prosesser må ha en egeninteresse for å delta, det avhenger ikke bare av at avdelingssykepleier legger til rette. Kanskje er det slik at skolens ansatte er mer opptatt av teori enn å se den virkeligheten sykepleierne opplever i det daglige. Vår erfaring tilsier at lærer bør være til stede i avdelingen sammen med studentene og pleiepersonell og at lærer og studentansvarlig sykepleier samarbeider om de svake studentene. Dette forutsetter at både lærer og sykepleier er bevisst sin egen rolle knyttet til studentveiledning.

\section{Veiledning}

Sykepleier i praksis har i dag fått større ansvar for veiledning og oppfølging av sykepleierstudentene (21). Mange opplever dette ansvaret som krevende, men også spennende. De fleste kontaktsykepleierne i prosjektet hadde ansvar for to studenter hvor studentene gikk i tospann. At studentene er på forskjellig nivå blir nevnt av flere som utfordrende. Studentene har i hovedsak en positiv oppfatning av kontaktsykepleier når det gjelder oppfølging og kunnskap. Kunnskapsrike kontaktsykepleiere blir framhevet. Studentene verdsetter også tilgjengelighet og det å bli sett. Gode rollemodeller framheves som viktig og Tåsenhjemmet framstår som et godt sted å være i praksis. Studentene som er misfornøyde med kontaktsykepleierne begrunner dette med manglende tilstedeværelse på grunn av sykdom eller ferie. Noen studenter forteller om språkproblemer som gjør at misforståelser lett kan oppstå.

\section{I hvitt}


Lærerveilederne «gikk i hvitt» en til to ganger i uka og hadde veiledningsdager med studentene hvor de var med i stell. Nesten alle studentene var fornøyde med rollen lærer har hatt i praksisperioden. De opplevde nærhet, at de ble sett, fikk god oppfølging, og at lærerne var tilgjengelige og stilte krav til dem. De som ikke var fornøyde kritiserte pedagogiske metoder og manglende evne hos lærer til å gi konstruktiv kritikk og ros. Det var heller ikke alle som satte pris på at læreren var med på morgenstellet.

\section{Tilgjengelighet}

Sykepleier forventer at lærer skal gi retningslinjer for veiledning, være rådgiver for kontaktsykepleier, kontaktperson mellom student og sykepleier samt forberede og planlegge praksisperioden. De ønsker at læreren er synlig og tilgjengelig og at han eller hun tar tak i problemer som oppstår. Mange er fornøyde slik det er i dag, mens andre ønsker at lærerne er mer til stede i praksis. Samtlige synes de det er positivt at læreren går i hvitt og er med studentene i stell. En sykepleier skriver: (Det er) en nødvendighet for aktivt å observere i situasjonen, til tross for at det kan være noe stressende for studenten. Viktig å ha faglig diskusjon etterpå ... bør observere gjennom hele dagen - hvordan studentene møter de fysiske, psykiske og sosiale behovene hos beboer. Ved å kle seg i hvitt ble lærerveileder en legitim del av praksisfellesskapet (10). Lærerne opplevde selv at det å gå i hvitt når de veiledet studentene var viktig. Nærhet, både til pleiepersonalet og praksissituasjonen, bidro til å synliggjøre både svakheter og styrker hos studenten. Flere studier konkluderer med at et godt samarbeid mellom ansatte i høyskole og praksis er svært viktig for studentenes praksisopplæring (19, 20). Derfor er rolleavklaring svært viktig i det videre samarbeidet mellom høyskoler og praksis.

\section{Trygghet og tid}


Samarbeidsprosjektet mellom Tåsenhjemmet og Høgskolen i Oslo og Akershus viser at nærhet, tillit, trygghet og tid er viktig for samarbeidet og et aktivt læringsmiljø. At lærer og kontaktsykepleier var til stede i praksis over tid betydde også mye.

Tospannmodellen med kontaktsykepleierordning og at lærer «går i hvitt» sammen med studentene og sykepleiere fremmer samarbeid. Til sammen bidro dette til å utvikle kunnskap i praksis gjennom eksempelvis kunnskapsbasert sykepleie. Tåsenhjemmet erfarte det som positivt å ta imot et større antall studenter og vil videreføre samarbeidsprosjektet.

Faste samarbeidsmøter er viktig. Det forberedende møtet hvor kontaktsykepleiere, fagutviklingssykepleiere og lærere møtes før studentene kommer, skaper forutsigbarhet og rom for å diskutere faglige og pedagogiske spørsmål og avklare roller. Velkomstmøte og de faglige fellesmøtene fortsetter, men hensikten må være klar og møtene kontinuerlig evalueres. Fagutviklingssykepleier vil fortsatt fungere som bindeledd mellom høyskole og sykehjem. Det er et felles ansvar å motivere til sykepleiefaglig engasjement. Vi tror våre erfaringer vil være nyttige for andre lærere og sykepleiere med ansvar for studenter slik at sykehjem kan leve opp til Tåsenhjemmets visjon: et godt og trygt sted å være for både pasienter og pårørende, pleiepersonalet, studenter og lærere.

\section{Litteratur}


1. Malterud K. Kvalitative metoder i medisinsk forskning: en innføring. Oslo: Universitetsforlaget, 2003.

2. Fagermoen MS. Sykepleie: fag og utdanning. Oslo: Universitetsforlaget, 1981.

3. Bjerknes MS, Kollstad M, Granum V.

Praksisundervisning i sykepleierutdanningen:

kunnskap, undervisning, læring i praksisfeltet. Oslo:

Gyldendal, 1988.

4. Bjerknes MS, Bjørk IT. Praktiske studier: perspektiver på refleksjon og læring. Oslo: TANO, 1994.

5. Bjørk IT, Bjerknes MS. Å lære i praksis: en veiviser for studenten. Oslo: Universitetsforlaget, 2003.

6. Heggen K. Sykehuset som «klasserom»: praksisopplæring i profesjonsutdanninger. Oslo: Universitetsforlaget, 1995.

7. Benner P, Heggen K. Å utdanne sykepleiere: behov for radikale endringer. Oslo: Akribe, 2010.

8. Jarvis P, Gibson S. The teacher practitioner and mentor in nursing, midwifery, health visiting and the social services. UK: Stanley Thornes, 1997.

9. Jensen KT. Å være student i en feltbasert utdanning: en analyse av studenters fellesskap, som kontekst for læring og identitetsdannelse. Oslo: Unipub forlag, 2006.

10. Nygren P. Handlingskompetanse: om profesjonelle personer. Oslo: Gyldendal akademisk, 2004.

11. Kristoffersen NJ, Lillemoen L. Group supervison for nurses responsible for student follow-up in clinical practice: developing competence in supervision. Norsk Tidsskrift for Sykepleieforskning 2010;12(2): 3-14.

12. Dau S, Nielsen G. Educational barriers in the development of the clinical nursing profession. Klinisk Sygepleje 2011;25(2): 66-76.

13. Flateland S, Kristiansen A, Söderhamn U. Nursing students> learning - learning in practice through participation in a reflection group. Nordisk Sygeplejeforskning 2011;1(1): 5-18.

14. Benner P. Fra novise til ekspert: dyktighet og styrke i klinisk sykepleiepraksis. Oslo: I samarbeid 
med Munksgaard, 1995.

15. Bryn V, Hovdsveen RK, Slettebö Å, Syvertsen AL, Veitsle KC. Home care services: clinical practice in pair. Sykepleien Forskning 2009;4(1): 44-50.

16. Wenger E. Praksisfællesskaber: læring, mening og identitet. København: Reitzel; 2004.

17. Nortvedt MW, Jamtvedt, G. Gravholt, B., Reinar L.M A arbeide og undervise kunnskapsbasert: en arbeidsbok for sykepleiere. Oslo: Norsk Sykepleierforbund, 2007.

18. Bjørk IT, Solhaug M. Fagutvikling og forskning i klinisk sykepleie: en ressursbok. Oslo: Akribe, 2008. 19. Koontz AM, Mallory JL, Burns JA, Chapman S. Staff nurses and students: the good, the bad, and the ugly. Medsurg Nursing: Official Journal Of The Academy Of Medical-Surgical Nurses 2010;19(4): 240.

20. Dunn SV, Hansford B. Undergraduate nursing students> perceptions of their clinical learning environment. Journal of Advanced Nursing 1997;25(6): 1299-306.

21. Grönvold L, Solvoll B-A. Clinical supervisors〉 opinions on nursing students> written reflections. Norsk Tidsskrift for Sykepleieforskning 2010;12(3): 48-58. 